\title{
REFORMULASI PENGATURAN APLIKASI I-DOSER SEBAGAI NARKOTIKA DIGITAL
}

\author{
Jufryanto Puluhulawa \\ Universitas Negeri Gorontalo \\ J1. Jenderal Sudirman No. 6 Gorontalo \\ Email: ryanpuluhulawa@gmail.com
}

Diterima: 13 September 2016 | Direview: 10 Oktober 2016 | Disetujui: 26 Nopember 2016

\begin{abstract}
I-Doser Application in smartphone had caused public anxiety and seized greater attention. The purpose of this research is to analyze whether the I-Doser Application application could be put into new narcotic category, to understand and to analyze the impact of law vacuum in I-Doser Application arrangement if understood from law certainty perspective, and to analyze law reformulation policy against I-Doser Application as digital narcotic through Indonesia's ius constituendum. This is a normative research using statute, conceptual and comparative approaches. Result of this research indicated that I-Doser Application was viewed as the base concept of narcotic thus considered as new narcotic category. The implication of law vacuum, I-Doser Application had embedded its hegemony deeper that could ruin national well-being in the future unless a concrete law measure was taken, so that the necessary law reformulation policy against I-Doser Application as digital narcotic within Indonesia's ius constituendum.
\end{abstract}

Key words: reformulation, arrangement, I-Doser application, narcotic, digital

\begin{abstract}
Abstrak
Aplikasi I-Doser yang terdapat pada smartphone menimbulkan keresahan dan menyita perhatian publik. Penulisan ini bertujuan untuk menganalisa aplikasi I-Doser apakah dapat dikategorikan sebagai narkotika baru, memahami dan menganalisa dampak dari kekosongan hukum pengaturan tentang I-Doser dalam perspektif kepastian hukum dan menganalisa kebijakan reformulasi hukum terhadap aplikasi I-Doser sebagai narkotika digital dalam ius constituendum di Indonesia. Penulisan menggunakan jenis penelitian hukum normatif dengan pendekatan undang-undang, konseptual dan komparatif. Hasil pembahasan, aplikasi I-Doser merujuk pada konsep dasar narkotika, dapat dikategorisasikan sebagai narkotika baru. Dampak dari kekosongan hukum, aplikasi I-Doser semakin menancapkan hegemoninya untuk merusak generasi bangsa kedepannya tanpa bisa diberikan sebuah langkah hukum yang kongkrit, sehingga diperlukan kebijakan reformulasi aturan hukum terhadap aplikasi I-Doser sebagai narkotika digital dalam ius constituendum di indonesia.
\end{abstract}

Kata kunci: reformulasi, pengaturan, aplikasi I-Doser, narkotika, digital

\section{Latar Belakang}

Semakin canggihnya smartphone yang dipasarkan maka semakin banyak pula aplikasi yang bermunculan guna mendukung kinerja dari smartphone tersebut. Bagaikan dua sisi mata uang, ada aplikasi yang sangat berguna dan memberikan manfaat positif bagi penggunanya tapi ada juga aplikasi 
yang berdampak negatif bagi para pengguna smartphone. Salah satu dari sekian banyaknya aplikasi yang saat ini menyita perhatian khalayak umum dan ramai diperbincangkan saat ini adalah $I$-Doser.

I-Doser menggunakan gelombang suara khusus, dimana gelombang suara tersebut digunakan untuk menstimulasi, merangsang, mempengaruhi atau mensinkronisasi otak penggunanya. Teknologi ini kemudian dikenal secara universal dengan sebutan brainwave entrainment dimana dalam mekanisme kerjanya menggunakan gelombang suara yang disebut binaural beats. Hal ini sebagaimana diutarakan oleh Tina L. Huang yakni ${ }^{1}$

"The term brainwave entrainment refers to the use of rhythmic stimuli with the intention of producing a frequency-following response of brainwaves to match the frequency of the stimuli. The stimulus is usually either visual (flashing lights) or auditory (pulsating tones). By those in the industry, it is also commonly called "brain entrainment," "audiovisual entrainment (AVE)," "audiovisual stimulation (AVS)," "auditory entrainment," or "photic stimulation."

"(rangsangan gelombang otak merupakan istilah yang mengacu pada penggunaan berirama rangsangan dengan tujuan menghasilkan frekuensi-berikut respon gelombang otak agar sesuai dengan frekuensi dari rangsangan. Stimulus biasanya baik visual (penglihatan) atau pendengaran (ketukan nada). Oleh orang-orang di industri, juga sering disebut rangsangan otak, audiovisual entrainment (AVE) atau rangsangan audiovisual (AVS), rangsangan pendengaran atau stimulasi fotik). ${ }^{2}$

Tujuan awal dari I-Doser yang menggunakan Binaural Beats adalah hanya untuk keperluan medis berupa terapi bagi para penderita penyakit tertentu dimana menurut Asosiasi Parapsikoterapi Indonesia menyatakan bahwa ${ }^{3}$

$\begin{array}{ccc}\text { "I-Doser } & \text { dipergunakan } & \text { untuk } \\ \text { membantu } & \text { pasien } & \text { dalam }\end{array}$ mempercepat proses penyembuhan, mengatasi masalah psikologis dan fobia, membantu mengatasi masalah rasa percaya diri dan mentalitas, meningkatkan kecerdasan dan kemampuan otak anda, membantu mengatasi stress, perawatan dan kecantikan tubuh serta mengurangi rasa sakit yang ada dalam tubuh melalui relaksasi."

Hadirnya I-Doser dalam bentuk aplikasi di smartphone menjadikannya bebas untuk dikonsumsi publik dan rentan disalahgunakan. I-Doser ini dalam beberapa artikel yang penulis telusuri bahwasannya bisa mempengaruhi kesadaran seseorang bahkan mempengaruhi atau mengubah mood atau perasaan dari orang tersebut. Le Scouarnec RP

1 Tina L. Huang. "A Comprehensive Review Of The Psychological Effects Of Brainwave Entrainment". Alternative Therapies Vol. 14, No. 5, (Sep/Oct 2008): 38, https://www.transparentcorp.com/downloads/HuangPsychologicalEffectsBrainwaveEntrainment.pdf, diakses 14 Desember 2015.

2 Koersif Penulis.

3 Asosiasi Parapsikoterapi Indonesia, "Terapi Binaural Beats", http://www.binauralbeats.co.id/, diakses 31 Oktober 2015. 
dkk menjelaskan" "Listening to the binaural beat tapes resulted in a significant reduction in the anxiety score reported daily in patients' diaries" (Mendengarkan kaset binaural beat mengakibatkan penurunan yang signifikan dalam rataan kecemasan yang dilaporkan harian di buku harian pasien). ${ }^{5}$ Selaras dengan hal tersebut, James D. Lane dan Stefan J. Kasian dkk, menyatakan ${ }^{6}$

"The observations in the present study have interesting implications. If binaural beat auditory stimulation can influence behavior and mood, then such stimulation may have useful applications for the selfcontrol of arousal, attention, and performance."

(Pengamatan dalam penelitian ini memiliki implikasi yang menarik. Jika stimulasi mendengarkan binaural beat dapat mempengaruhi perilaku dan suasana hati, maka stimulasi tersebut dapat digunakan dalam aplikasi yang berguna untuk pengendalian diri dari gairah, perhatian, dan kinerja). ${ }^{7}$
Bahkan pada kasus tertentu, seperti dimuat dalam Jurnal Riau, ${ }^{8}$ "pengguna I-Doser disebut-sebut akan mengalami ketergantungan dan merasakan efek $f y$ seperti saat mengonsumsi narkotika. Diberitakan ICMI $^{9}$ di Oklahoma, Amerika Serikat, banyak anak-anak yang kecanduan I-Doser, salah satunya para murid sekolah Mustang High School." $" 10$

Permasalahan kemudian timbul ketika I-Doser dianggap bukan sebagai sebuah narkotika khususnya dikategorikan sebagai narkotika digital dalam hal ini, dikarenakan pengaturan mengenai pengertian narkotika itu sendiri dalam Pasal 1 Undang-Undang No. 35 Tahun 2009 Tentang Narkotika. ${ }^{11}$ Narkotika digital yang disebut dengan I-Doser ini jelas jika dilihat dari aspek yuridis dengan berpatokan pada bunyi dari Pasal 1 UndangUndang Nomor No. 35 Tahun 2009 Tentang Narkotika bukan merupakan sebuah zat atau obat apalagi berasal dari tanaman.

4 Le Scouarnec RP dkk, "Use of binaural beat tapes for treatment of anxiety: a pilot study of tape preference and outcomes", AlternTher Health Med. Volume 7, No. 1, (Januari 2001): 58-63. http://crawl.prod.proquest.com. s3.amazonaws.com/fpcache/beecd31634767586ab344700c70e533b.pdf., diakses 14 Desember 2015.

5 Koersif Penulis.

6 James D. Lane dan Stefan J. Kasian dkk, Binaural Auditory Beats Affect Vigilance: Performance and Mood, (Virginia: The Center for the Study of Complementary and Alternative Therapies, 1997), p. 7.

7 Koersif Penulis.

8 Jurnal Riau, "BNN Tak Bisa Larang Netizen Unduh I-Doser”, http://www.jurnalriau.com/read, diakses 10 November 2015.

9 Ikatan Cendekiawan Muslim Se-Indonesia, "BNN Masih Dalami Perihal I-Doser”, http://www.icmi.or.id/, diakses 28 Oktober 2015.

10 Ibid.

11 Narkotika adalah "zat atau obat yang berasal dari tanaman atau bukan tanaman, baik sintetis maupun semisintetis, yang dapat menyebabkan penurunan atau perubahan kesadaran, hilangnya rasa, mengurangi sampai menghilangkan rasa nyeri, dan dapat menimbulkan ketergantungan, yang dibedakan ke dalam golongangolongan sebagaimana terlampir dalam undang-undang ini." 
Di Indonesia sebagaimana diberitakan oleh CNN Indonesia, "kehadiran I-Doser telah menimbulkan keresahan dalam masyarakat dan menyita perhatian khalayak ramai", ${ }^{12}$ sehingga sudah semestinya dilakukan langkah hukum untuk mengatasi permasalahan tersebut sebelum keresahan tersebut meningkat menjadi sebuah gejolak dalam masyarakat yang tentunya tidak baik bagi jalannya roda pemerintahan dan tatanan berbangsa dan bernegara serta kehidupan bermasyarakat tentunya.

Jika melihat pada Pasal28D ayat (1) ${ }^{13}$, Pasal 28G ayat (1) $)^{14}$, Pasal $28 \mathrm{H}$ ayat (1) ${ }^{15}$ UndangUndang Dasar Negara Republik Indonesia Tahun 1945 maka sebagai warga negara dalam kehidupan berbangsa dan bernegara sepatutnya mendapatkan ketenangan dan ketentraman dalam menjalani kehidupannya dalam berbagai aktivitas yang dijalaninya, akan tetapi dengan adanya aplikasi I-Doser yang dapat diunduh secara bebas sehingga sangat rentan disalahgunakan oleh siapapun terlebih lagi saat ini hegemoni smartphone sedang berada dipuncaknya, maka warga negara dalam hal ini masyarakat secara umum menjadi khawatir dan resah sehingga jaminan akan perlindungan hukum yang seharusnya mereka dapatkan serta lingkungan yang baik dan sehat sebagaimana diamanatkan oleh Undang-Undang Dasar Negara Republik Indonesia Tahun 1945, tidak mereka dapatkan secara utuh.

Seiring perkembangan ilmu pengetahuan dan teknologi maka tentunya tidak menutup kemungkinan, dimasa yang akan datang narkotika digital akan menjadi sebuah permasalahan serius yang harus dihadapi dan ditangani oleh negara ini sehingga adanya kekosongan hukum dalam Undang-Undang Nomor 35 Tahun 2009 Tentang Narkotika dan juga pentingnya mengambil langkah hukum untuk menanggulangi permasalahan I-Doser sebagai narkotika digital ini tentunya menjadi topik yang menarik untuk diteliti.

Berdasarkan latar belakang tersebut, timbul permasalahan antara lain apakah aplikasi I-Doser dapat dikategorikan sebagai narkotika baru dan apa implikasi yuridis dari kekosongan aturan tentang I-Doser dalam perspektif kepastian hukum serta bagaimana kebijakan formulasi aturan hukum terhadap aplikasi I-Doser sebagai narkotika digital dalam ius constituendum di Indonesia.

Penulisan tesis ini menggunakan penelitian hukum normatif dengan metode pendekatan konseptual (conceptual approach), metode pendekatan undang-undang (statute

12 Safyra Primadhyta, "Kominfo Blokir Sementara Situs Narkoba Digital I-Doser", http://www.cnnindonesia. com/teknologi/, diakses 10 Agustus 2016.

13 Setiap orang berhak atas pengakuan, jaminan, perlindungan, dan kepastian hukum yang adil serta perlakuan yang sama di hadapan hukum.

14 Setiap orang berhak atas perlindungan diri pribadi, keluarga, kehormatan, martabat, dan harta benda yang dibawah kekuasaannya, serta berhak atas rasa aman dan perlindungan dari ancaman ketakutan untuk berbuat atau tidak berbuat sesuatu yang merupakan hak asasi.

15 Setiap orang berhak hidup sejahtera lahir dan batin, bertempat tinggal, dan mendapatkan lingkungan hidup yang baik dan sehat serta berhak memperoleh pelayanan kesehatan. 
approach) dan metode pendekatan komparatif (comparative approach). Jenis Bahan Hukum yang digunakan adalah bahan hukum primer yang terdiri dari Resolution III Social Conditions And Protection Against Drug Addiction Single Convention on Narcotic Drugs 1961, Colorado Amendment 64 Regulate Marijuana Like Alcohol Act of 2012, Pasal 28 D ayat (1), Pasal 28 G Ayat (1), Pasal 28 H Ayat (1) dan Pasal 28 I Ayat (4) UndangUndang Dasar Republik Indonesia 1945, Pasal 1 Undang-undang Nomor 1 Tahun 1946 tentang Kitab Undang-undang Hukum Pidana (KUHP), Pasal 1 Ayat (1) Undang-undang Nomor 35 Tahun 2009 tentang Narkotika. kemudian untuk bahan hukum sekunder terdiri dari buku - buku yang membahas mengenai narkotika, karya tulis dari kalangan hukum mengenai narkotika, hasil - hasil penelitian mengenai narkotika, hasil kesimpulan seminar, makalah, artikel, ceramah, kuliah mengenai narkotika. sedangkan untuk bahan hukum tersier, menggunakan Kamus Hukum, Kamus Besar Bahasa Indonesia dan Terminologi Hukum Inggris - Indonesia. Sinar Grafika. Jakarta. 2008. teknik pengumpulan bahan hukum dalam penulisan tesis ini menggunakan studi pustaka, sedangkan untuk teknik analisis bahan hukum menggunakan metode intepretasi gramatikal, teleologis, futuristik dan intepretasi ekstensif.

\section{Pembahasan}

\section{A. Kategorisasi Aplikasi I-Doser Sebagai Narkotika Digital}

Pemikiran untuk mengkategorisasi aplikasi I-Doser sebagai narkotika baru, baik dilihat dari model atau jenisnya tentu harus beranjak dari konsep mengenai narkotika itu sendiri. Membicarakan konsep dasar narkotika maka haruslah merujuk pada asal muasal dari kata narkotika itu sendiri, dimana hasil penelusuran yang penulis lakukan, "narkotika berasal dari kata narkon yang berasal dari Bahasa Yunani, yang artinya beku dan kaku, dalam ilmu kedokteran juga disebut Narcose atau Narcicis yang berarti membiuskan."16

Dilihat dari perspektif etimologis, istilah narkotika berasal dari kata marke (Bahasa Yunani) yang berarti terbius sehingga menjadi mati rasa atau tidak merasakan apa-apa lagi." ${ }^{17}$ Merujuk pada pengertian tersebut maka narkotika identik dengan sesuatu yang bersifat menghilangkan sensasi yang biasanya timbul dari reaksi biologis alamiah tubuh dalam merespon sesuatu hal di sekitarnya.

I-Doser dalam berbagai penelitian menunjukkan binaural beats yang terdapat dalam aplikasi I-Doser berimplikasi secara signifikan terhadap kesadaran individu yang menggunakannya sehingga jika beranjak dari konsep dasar narkotika, dikaitkan dengan I-Doser maka dalam pandangan penulis, I-Doser sebenarnya dapat dikategorisasikan

16 Ikin A. Ghani, "Pengertian Narkotika Menurut Ahli", http://documents.tips/, diakses 22 April 2016.

17 I Nyoman Nurjaya, "Penanggulangan Kejahatan Narkotika: Eksekusi Hak Perspektif Sosiologi Hukum”, ejournal.umm.ac.id, diakses 22 April 2016. 
sebagai narkotika baru karena intisari dari kategori narkotika sebenarnya terletak pada efek samping yang ditimbulkannya bukan pada bentuk atau jenisnya. Pemikiran ini dilandaskan bahwa dalam berbagai literatur mengenai narkotika yang penulis telusuri, penulis mendapatkan satu pemahaman, para ahli memiliki berbagai penafsiran akan narkotika itu sendiri.

Terdapat berbagai definisi mengenai narkotika tetapi dari kesemuanya ada satu kesepahaman pandangan terkait dampak yang ditimbul dari penggunaan narkotika yakni mengurangi bahkan menghilangkan sensitifitas atau kepekaan dari panca indra, mengurangi bahkan menghilangkan rasa sakit, menciptakan perasaan tenang bahkan dapat mendorong rasa kantuk yang menyebabkan tertidur dan pada tingkat yang cukup parah atau dengan kata lain adanya penggunaan yang berlebihan terhadap narkotika yang dikenal dengan istilah overdosis, akan menyebabkan pingsan, kejang, koma atau tidak sadarkan diri bahkan dapat menyebabkan kematian jika digunakan secara berlebihan.

Berangkat dari hal inilah kemudian penulis memiliki pandangan bahwa narkotika dari waktu ke waktu akan terus mengalami transformasi baik itu jenis, bentuk maupun modelnya, sebagai bagian dari perkembangan ilmu pengetahuan, kecanggihan teknologi serta pola pikir dari para pihak yang memiliki kepentingan didalamnya, dimana para pihak terkait ini akan terus mengembangkan modus operandi terbaru bahkan menciptakan narkotika baru agar tetap bisa meraup keuntungan dari bisnis haram ini. Semua hal baru terkait narkotika ini pada intinya adalah menciptakan efek negatif yang sama. Apapun bentuknya, bagaimanapun jenisnya dan seperti apapun modelnya, efek yang ditimbulkannya tetaplah berujung pada tiga hal yang menurut Howard Abadinsky yakni ${ }^{18}$ "depressants, stimultant, dan hallucinogens".

Narkotika pada dasarnya dikonsumsi dengan berbagai cara. Ada yang ditelan jika bentuknya adalah berupa obat-obatan, disuntik dengan menggunakan jarum suntik jika bentuknya berupa cairan dan dihirup jika bentuknya serbuk. Kesemua cara tersebut pada intinya adalah untuk mempengaruhi kinerja dari otak dengan perantara aliran darah. Hal ini jelas sama halnya dengan I-Doser yang melalui gelombang suara, hanya saja proses masuknya melalui sistem pendengaran bukan sistem pembuluh darah tetapi pada akhirnya juga akan mempengaruhi kinerja dari otak penggunanya. Disini terlihat bahwasannya I-Doser memiliki keterkaitan erat dengan narkotika yang selama ini kita kenal.

Meriam Webster ${ }^{19}$ juga mengungkapkan secara jelas mengenai konsep dari narkotika itu sendiri yang tidak hanya terbatas pada sesuatu yang berbentuk obat-obatan atau zat, tetapi lebih luas lagi juga melingkupi sesuatu

18 Howard Abadinsky, Drug Use and Abuse, A Comprehensive Introduction, 8th Edition, (United States of America: Wadsworth Cengage Learning, 2014), pp. 39-124.

19 Meriam-Websters, "Full Definition Of Narcotic", http://www.merriam-webster.com/dictionary/narcotic, diakses 29 Maret 2016. 
yang bersifat menenangkan, meringankan dan menidurkan. Jika hanya membatasi peraturan pada pengaturan mengenai zat atau obat, maka hukum akan selalu tertinggal padahal perkembangan narkotika baik itu dari jenis, model, modus operandi maupun tingkat peredarannya mengalami peningkatan yang luar biasa dari waktu ke waktu.

Patut kiranya untuk menyimak dan merujuk konsep yang diutarakan Meriam Webster tersebut karena hukum sepantasnya berkarakter progresif dan futuristik sehingga bersifat antisipatif bukan lebih banyak menekankan pada sifat responsif. Hal ini tentunya sejalan dengan pepatah yang mengatakan lebih baik mencegah daripada mengobati.

Penegasan keterkaitan I-Doser dengan narkotika juga terlihat pada adanya benang merah antara I-Doser dengan narkotika dapat disimak dari pernyataan Harifin A. Tumpa yakni20 "narkotika ditujukan untuk mempengaruhi susunan biokimiawi molekul sel otak pada sistem limbus yakni bagian otak yang bertanggung-jawab atas kehidupan perasaan, dimana dalam Limbus yaitu pusat kenikmatan otak yang disebut neurotransmitter." Ketika penggunaannya dirasa cocok dan menghasilkan sebuah kenikmatan, ketenangan dan rasa gembira maka otakmelalui neuro-transmitter akan meresponnya dalam bentuk tindakan untuk terus menggunakan atau mengulangi penggunaannya yang berujung pada kecanduan.

Perkembangan terkini, Pemerintah Indonesia melalui Kementerian Komunikasi dan Informatika, pada bulan Oktober 2015 membuat sebuah langkah penanganan secara resmi dengan melakukan pemblokiran terhadap beberapa situs website yang memiliki kaitannya dengan penyebaran I-Doser. Langkah yang diambil oleh Pemerintah Indonesia ini dapat diartikan sebagai bentuk pernyataan sikap pemerintah secara tidak langsung atau dengan kata lain, penulis menganggapnya sebagai penegasan tersirat bahwasannya pada hakikatnya, I-Doser dimata Pemerintah Indonesia dipandang sebagai sesuatu yang berbahaya, yang jika dibiarkan secara terus-menerus dalam jangka waktu tertentu berpotensi menjadi sebuah ancaman serius bagi kedaulatan negara.

Patut disayangkan, usaha pemerintah ini tidaklah optimal dan tidak berjalan sesuai dengan apa yang diharapkan. Pemblokiran situs ini hanya dilakukan bagi website yang bisa diakses melalui Personal Computer maupun layanan browser sedangkan akses dari layanan Appstore sama sekali tidak dilakukan pemblokiran sehingga I-Doser bisa diakses dengan begitu bebasnya, padahal penggunaan smartphone di Indonesia sendiri seperti diberitakan oleh techno.okezone.com ${ }^{21}$ bahwa "pada akhir 2015 diperkirakan sekitar 55 juta pengguna smartphone di Indonesia. Sedangkan total penetrasi pertumbuhanya

20 Harifin A, Tumpa, Komentar dan Pembahasan UU No. 35 Tahun 2009 tentang Narkotika, (Jakarta: Sinar Grafika, 2013), hlm. 5.

21 Advent Jose, "Pengguna Smartphone di Indonesia Capai 55 Juta", http://techno.okezone.com/read/2015, diakses 1 April 2016. 
mencapai 37,1 persen," sedangkan riset dari Lembaga riset digital marketing Emarketer, ${ }^{22}$ diperkirakan pada 2018 jumlah pengguna aktif smartphone di Indonesia lebih dari 100 juta orang. Penetrasi pertumbuhan penggunaan smartphone tersebut dapat dilihat dari Diagram 1.

Maka jika dikaitkan dengan paradigma penggunaan aplikasi I-Doser saat ini, perlu adanya sebuah pandangan futuristik terhadap

\section{Diagram 1. Penetrasi Pertumbuhan Penggunaan Smartphone dari 2013-2018 ${ }^{23}$}

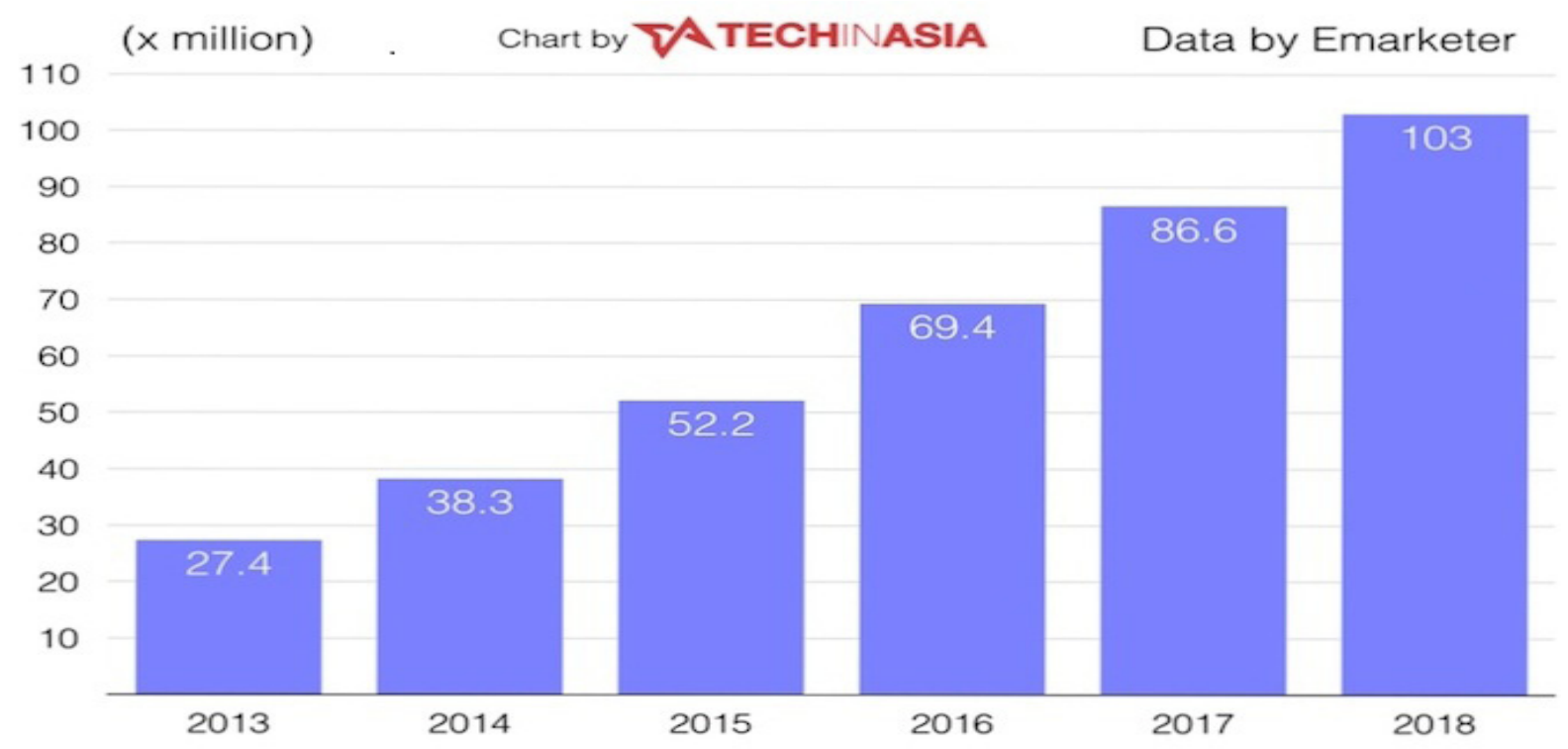

Sumber: https://id.techinasia.com/jumlah-pengguna-smartphone-di-indonesia-2018

pengaturan hukum terkait perkembangan dari pengembangan dan pemanfaatan gelombang suara khusus yang dikemas dalam balutan teknologi mutakhir di masa yang akan datang baik itu mengatasnamakan I-Doser maupun aplikasi-aplikasi sejenis dengan nama yang berbeda.
B. Implikasi Yuridis dari Kekosongan Aturan Mengenai Pengaturan Tentang I-Doser dalam Perspektif Kepastian Hukum

Negara Indonesia adalah negara hukum, hal ini tergambarkan dengan jelas dalam Pasal 1 ayat (3) Undang-Undang Dasar Negara Republik Indonesia Tahun 1945, Realitanya saat ini, penegakan dan penerapan hukum tersebut seringkali terganjal oleh kemajuan

22 Kementerian Komunikasi dan Informatika, “Indonesia Raksasa Teknologi Digital Asia”, https://kominfo.go.id/ index.php/content/detail, diakses 2 April 2016.

23 Steven Millward, "Indonesia diproyeksi lampaui 100 juta pengguna smartphone di 2018, keempat di dunia", https://id.techinasia.com/jumlah-pengguna-smartphone-di-indonesia-2018, diakses 3 April 2016. 
yang ada dalam masyarakat. Masyarakat tumbuh dan berkembang dengan begitu pesatnya, saking pesatnya hingga memberikan suatu pandangan bahwa hukum, dalam hal ini aturan perundang-undangan, selalu tertinggal jauhdibelakang padahalhadirnyahukumdalam kehidupan masyarakat sangat diperlukan guna mengkondisikan suasana yang harmonis dan terorganisir dalam kehidupan berbangsa dan bernegara bagi masyarakatnya.

Kendala dari penegakan dan penerapan hukum itu sendiri juga menyasar pada permasalahan narkoba atau napza. Tentunya Pemerintah Indonesia bekerja dengan sangat keras dan melakukan pembenahan untuk melindungi Indonesia dari bahaya narkoba atau napza. Ditengah upaya keras Pemerintah Indonesia tersebut, ancaman bahaya narkotika terbaru muncul, dan lebih menariknya lagi karena narkotika ini berwujud bukan dalam bentuk atau jenis baru yang masih pada umumnya berbentuk obat-obatan tetapi bersumber dari smartphone dalam balutan aplikasi yang bernama I-Doser yang berwujud suara dengan menggunakan frekuensi tertentu yang dikenal dengan sebutan binaural beats dalam pola kerjanya.

Derasnya kemajuan teknologi informasi dan komunikasi serta proses globalisasi menuntun pada transfer nilai-nilai yang berujung pada perubahan cara pandang dan gaya hidup yang lebih berorientasi pada modernitas, individualitas, konsumtif dan hedonisme. Akibatnya adalah kehidupan penuh dengan tantangan dan kompetisi sehingga pada akhirnya masyarakat menjadi lebih muda mengalami stress, frustasi dan mengalami ketegangan jiwa.

Masyarakat yang tidak sehat secara mental seperti ini kemudian akan mencari sebuah pelarian untuk dijadikan wadah pelampiasan dari tekanan hidup yang dialaminya. Disinilah kemudian aplikasi I-Doser masuk dan memainkan peranannya. Penggunaan narkotika, psikotropika dan zat adiktif jelas sangat berisiko tinggi. Maka kemudian orang akan cenderung mencari alternatif yang lebih mudah diakses dan tidak beresiko.

I-Doser hadir sebagai jawabannya dari permasalahan masyarakat modern saat ini. Mudah digunakan karena cukup bermodalkan sebuah perangkat smartphone beserta headset dengan kualitas baik, yang di masa ini hampir semua orang pasti memilikinya maka permasalahan mental yang dihadapi segera teratasi. Melalui binaural beats yang ada didalam I-Doser berimplikasi pada hilangnya stress, jiwa menjadi lebih tenang, tubuh lebih rileks, rasa cemas menurun dan hidup lebih bergairah.

Hidup yang serba instan, fleksibel dan selalu dikejar waktu seperti saat ini jelas memperparah efek kecanduan dari penggunaan dari I-Doser yang menggunakan Binaural Beats dalam menunjang kinerjanya ini karena penggunaannya tidak diawasi oleh tenaga medis yang terlatih dibidangnya sehingga penggunaannya menjadi membahayakan diri pengguna sendiri. Saat ini kecenderungannya adalah I-Doser dijadikan 
alternatif untuk mendapatkan sensasi selayaknya menggunakan narkotika yang berbentuk dan memiliki kandungan kimiawi pada umumnya.

Kecenderungan tersebut terlihat dari informasi yang dimuat dalam Jurnal Riau, ${ }^{24}$ "pengguna I-Doser disebut-sebut akan mengalami ketergantungan dan merasakan efek fly seperti saat mengonsumsi narkotika serta diberitakan oleh ICMI $^{25}$ bahwa di Oklahoma, Amerika Serikat, banyak anakanak yang kecanduan I-Doser, salah satunya para murid sekolah Mustang High School.”26

I-Doser yang dibalut oleh kecanggihan teknologi jelas lebih menarik antusias para remaja. Rasionalisasinya adalah jika isi dari spidol atau whiteboard marker serta lem FOX atau lem Aica-Aibon, sudah sangat menarik perhatian para remaja yang ingin merasakan sensasi fly dari menggunakan narkotika apalagi I-Doser yang telah dikemas dengan begitu futuristis. Dengan kata lain dari sudut pandang para penggunanya, I-Doser adalah alternatif aman untuk merasakan sensasi narkotika tanpa harus takut terjerat masalah hukum karena di Indonesia, narkotika yang berwujud saja masih banyak celah hukumnya apalagi narkotika digital seperti ini.
Melihat berbagai statement yang dirilis oleh Pemerintah Indonesia khususnya dalam hal ini adalah Badan Narkotika Nasional dan juga sikap yang diambil Pemerintah Indonesia dalam menyikapi permasalahan narkotika digital ini, jika dikaitkan dengan doktrin hukum pidana mengenai perbuatan pidana atau tindak pidana, maka penulis berpandangan Badan Narkotika Nasional atas nama Pemerintah Indonesia dalam hal ini menggunakan pandangan monistis dalam menyikapi kasus I-Doser sebagai narkotika digital ini.

Pandangan monistis adalah "suatu pandangan yang melihat keseluruhan syarat untuk adanya pidana itu, kesemuanya merupakan sifat dari perbuatan." ${ }^{27}$ Pernyataan lainnya dari J. Bauman yakni28 "perbuatan pidana atau tindak pidana adalah perbuatan yang memenuhi rumusan delik, bersifat melawan hukum dan dilakukan dengan kesalahan."

Pandangan monistis ini jika dikaitkan dengan Pasal 1 ayat (1) Undang-undang Nomor 35 Tahun 2009 tentang Narkotika ${ }^{29}$ dalam memandang permasalahan I-Doser, jelas menciptakan sebuah kekosongan hukum didalamnya, disebabkan ada unsur zat atau

24 Jurnal Riau, loc.cit.

25 Ikatan Cendekiawan Muslim Se-Indonesia, loc.cit.

26 Ibid.

27 Soedarto dalam Tongat, Dasar-Dasar Hukum Pidana Indonesia Dalam Perspektif Pembaharuan, (Malang: UMM Press, 2008), hlm. 105.

28 Ibid., hlm. 106.

29 "Zat atau obat yang berasal dari tanaman atau bukan tanaman baik sintetis maupun semisintetis yang dapat menyebabkan penurunan atau perubahan kesadaran hilangnya rasa mengurangi sampai menghilangkan rasa nyeri dan dapat menimbulkan ketergantungan yang dibedakan ke dalam golongan-golongan sebagaimana terlampir dalam undang-undang ini." 
obat yang tidak terpenuhi dikarenakan I-Doser bukanlah zat atau obat.

Disisi lainnya, tidak ada undang-undang diluar Undang-undang Nomor 35 Tahun 2009 tentang Narkotika yang secara eksplisit mengatur tentang I-Doser itu sendiri untuk kemudian dapat dijadikan landasan hukum, padahal Indonesia menganut asas legalitas dimana pengaturan mengenai asas legalitas ini sendiri diatur dalam Pasal 1 ayat (1) Kitab Undang-undang Hukum Pidana dan Pasal 1 Rancangan Undang-Undang Kitab Undangundang Hukum Pidana yang menyatakan bahwa "tiada seorangpun dapat dipidana atau dikenakan tindakan kecuali perbuatan yang dilakukan telah ditetapkan sebagai tindak pidana dalam peraturan perundangundangan yang berlaku pada saat perbuatan itu dilakukan."

Dampaknya adalah aplikasi I-Doser terus merajalela dan semakin menancapkan hegemoninya untuk merusak generasi bangsa kedepannya tanpa bisa diberikan sebuah langkah hukum yang kongkrit guna mengatasi kerusakan yang ditimbulkan pada masa ini dan masa yang akan datang serta guna memberi jawaban atas keresahan yang dialami masyarakat selama ini.

Cepat atau lambat, invasi teknologi akan memberikan warna baru dan dampak yang besar dalam berbagai aspek kehidupan pada umumnya dan narkotika pada khususnya. Kekosongan aturan hukum tentunya tidak baik bagi kelangsungan dan eksistensi dari sebuah negara hukum seperti Indonesia ini.
Kekosongan aturan hukum berimplikasi pada tidak adanya kepastian hukum didalam masyarakat sehingga menyebabkan tatanan hidup masyarakat berjalan diluar jalur yang seharusnya. Sebabnya jelas yakni tidak adanya panduan yang dijadikan landasan berpikir, bertindak dan berperilaku bagi masyarakatnya.

Fenomena boomingnya penggunaan I-Doser di Indonesia merupakan implikasi dari kekosongan aturan hukum tersebut. Wajarlah jika I-Doser menjadi primadona di Indonesia karena ketiadaan aturan hukum membuat $I$-Doser berada diatas angin. Tidak terjangkau oleh aturan hukum sehingga para penggunanya merasakan sebuah kebebasan dan ketenangan dalam menggunakannya.

Masyarakat yang menggunakan bisa menikmati setiap harmoni dari nada yang dihasilkan dari aplikasi tersebut tanpa dihantui rasa takut akan sanksi hukum yang menjeratnya nanti, selayaknya penggunaan narkotika dan psikotropika serta zat adiktif pada umumnya selama ini. Pada akhirnya, ketika tidak ada payung hukum yang menaungi, ketertiban dan ketentraman masyarakat menjadi taruhannya. Kegaduhan dan keresahan akan muncul dan konflik pada akhirnya akan pecah. Pengguna I-Doser akan semakin merajalela dengan efek negatif yang selalu mengikutinya, sedangkan disisi lainnya bagi mereka yang tidak menggunakan aplikasi ini, tentu kondisi ini akan menciptakan ketidaknyamanan.

Disisi lain, hukum itu sendiri berfungsi untuk memberikan jaminan bagi seseorang 
agar kepentingannya diperhatikan oleh setiap orang lain. Jika kepentingan itu terganggu, maka hukum harus melindunginya dari setiap adanya pelanggaran hukum. Lawrence Friedman menyatakan bahwasannya hukum adalah" "kontrol sosial dari pemerintah (law is governmental social control), sebagai aturan dan proses sosial yang mencoba mendorong perilaku, baik yang berguna atau mencegah perilaku yang buruk." Ketika hukum tidak dapat memberikan perlindungannya maka yang terjadi adalah kekacauan dan kesemrawutan. Semua orang akan merasa digdaya untuk melakukan kehendaknya tanpa mempedulikan hak-hak atau kepentingkepentingan orang lain yang ada disekitarnya. Dampaknya, negara akan berada diambang kemerosotan moral yang menuju pada kehancuran suatu bangsa.

Lebih parahnya lagi, jika tidak dilakukan perubahan, akan terjadi transformasi. Narkotika digital akan dianggap sebagai bagian dari sebuah gaya hidup dan masyarakat akan mengamininya sebagai sesuatu yang normal dan bukanlah bagian dari sesuatu yang menyimpang. Pergeseran nilai menjadi tidak terelakkanjadinya.Halinidikarenakanmanusia memiliki kecenderungan untuk mengikuti apa yang diikuti dan diperbuat oleh sebagian besar masyarakat dalam lingkungannya tanpa mempertanyakan kebenaran hakiki dari apa yang dilakukan oleh mereka tersebut. Ketika I-Doser dipandang sebagai sebuah aplikasi musik pada umumnya dan penggunaannya dipandang sebagai sesuatu yang normal maka tinggal menunggu waktu, Negara Indonesia akan semakin terjerumus dalam bayangan gelap narkotika pada umumnya dan narkotika digital pada khususnya serta merejarelanya masyarakat yang tidak sehat secara mental.

\section{Kebijakan Reformulasi Aturan} Hukum terhadap Aplikasi I-Doser sebagai Narkotika Digital dalam

\section{Ius Constituendum di Indonesia}

Generasi bangsa ini berhak untuk mendapatkan jaminan atas kesejahteraan hidupnya dan kewajiban pemerintahlah untuk mencerdaskan generasi bangsa ini melalui perlindungan, pemajuan, penegakan dan pemenuhan hak asasi manusia warga negaranya. Kesemua jaminan atas warga negara tersebut telah dijabarkan dengan jelas dalam Alinea keempat bagian pembukaan Undang-Undang Dasar Negara Republik Indonesia $^{31}$ dan juga dalam Pasal 28I ayat (4) Undang-Undang Dasar Negara Republik Indonesia. $^{32}$

Kekosongan aturan hukum jelas tidak sehaluan dengan amanah Undang-Undang

30 Lawrence Friedman, American Law, (London: W.W. Norton \& Company, 1984), p. 3.

31 Pemerintah Negara Indonesia yang melindungi segenap bangsa Indonesia dan seluruh tumpah darah Indonesia dan untuk memajukan kesejahteraan umum, mencerdaskan kehidupan bangsa dan ikut melaksanakan ketertiban dunia yang berdasarkan kemerdekaan, perdamaian abadi dan keadilan sosial.

32 Perlindungan, pemajuan, penegakan, dan pemenuhan hak asasi manusia adalah tanggung jawab negara, terutama pemerintah. 
Dasar Negara Republik Indonesia Tahun 1945. Akibat dari kekosongan hukum ini sendiri yakni kekacauan hukum (rechtsverwarring) yang menimbulkan kebingungan dalam masyarakat akan hukum mana yang harus dipatuhi dan dilaksaksanakan serta hukum mana yang dapat dijadikan sebagai pedoman dalam tatanan bermasyarakat, berbangsa dan bernegara. Dampaknya arah kehidupan negara dan warga negaranya menjadi tidak menentu. Tentunya kondisi ini mengharuskan adanya respon cepat dalam menanggulanginya agar dampak yang ditimbulkan tidak semakin meluas dan merusak.

I Dewa Gede Palguna menyatakan, hal lainnya yang dijadikan pertimbangan untuk memberikan reaksi cepat dalam menanggulangi kekosongan hukum ini adalah untuk menjamin eksistensi Negara Republik Indonesia itu sendiri sebagai sebuah negara hukum, dimana salah satu ciri negara hukum adalah $^{33}$ "adanya legalitas dalam arti hukum, yakni bahwa baik pemerintah atau negara maupun warga negara dalam bertindak harus berdasar atas dan melalui hukum."

Sejalan dengan hal tersebut maka langkah konkret guna mengatasi kekosongan hukum ini adalah berupa mereformulasikan sebuah kebijakan yang mengatur secara lebih eksplisit mengenai narkotika digital dalam bentuk peraturan perundang-undangan khususnya dalam Undang-undang Nomor 35 Tahun 2009 tentang Narkotika. Langkah ini perlu dilakukan dengan pertimbangan bahwa teknologi semakin berkembang dengan cepat, masyarakat terus mengalami dinamika dalam kehidupannya yang tentunya mempengaruhi pola pikir, pola interaksi dan kebutuhan hidup masyarakatnya itu sendiri sehingga perlu kiranya untuk segera melakukan langkah antisipatif berupa reformulasi aturan hukum yang mengatur isu yang belum ada pengaturannya tersebut, guna menciptakan kepastian hukum, yang pada akhirnya dapat mengembalikan ketentraman dan ketertiban masyarakat yang sebelumnya terusik.

I-Doser yang digadang-gadang sebagai narkotika digital ini jelas telah menimbulkan kegaduhan sosial ditengah masyarakat sehingga kemudian sebagai bentuk dari usaha perlindungan masyarakat dan juga usaha untuk mensejahterakan masyarakat maka timbullah pemikiran untuk mengkriminalisasi aplikasi I-Doser sebagai narkotika digital ini.

Pertimbangan kriminalisasi terhadap suatu perbuatan dapat merujuk pada hasil Simposium Pembaruan Hukum Nasional di Semarang pada bulan Agustus 1980, dimana dalam simposium tersebut dalam kesimpulannya telah ditetapkan kriteria kriminalisasi yakni: ${ }^{34}$

1. "Apakah perbuatan itu tidak disukai

33 I Dewa Gede Palguna, Pengaduan Konstitusional (Constitutional Complaint), Upaya Hukum Terhadap Pelanggaran Hak-Hak Konstitusional Warga Negara, (Jakarta: Sinar Grafika, 2013), hlm. 533.

34 Barda Nawawi Arief, Bunga Rampai Kebijakan Hukum Pidana, Perkembangan Penyusunan KUHP Baru, Edisi Kedua, (Jakarta: Kencana Prenamedia Group, 2014), hlm. 32. 
atau dibenci oleh masyarakat karena merugikan, atau dapat merugikan, mendatangkan korban atau dapat mendatangkan korban."

2. "Apakah biaya mengkriminalisasi seimbang dengan hasil yang akan dicapai, artinya cost pembuatan undang-undang, pengurusan dan penegakan hukum serta beban yang dipikul oleh korban selaku pelaku dan pelaku kejahatan itu sendiri harus seimbang dengan situasi tertib hukum yang akan dicapai."

3. “Apakah makin menambah beban aparat penegak hukum yang tidak seimbang atau nyata-nyata tidak dapat diemban oleh kemampuan yang dimilikinya."

4. "Apakah perbuatan-perbuatan itu menghambat atau menghalangi citacita bangsa Indonesia, yaitu terciptanya masyarakat adil dan makmur, sehingga merupakan bahaya bagi keseluruhan masyarakat."

I-Doser melalui teknologi yang telah termuktahirkan ini, menjadi sesuatu yang berbahaya karena tidak ada pengawasan ketat akan penggunaannya serta akses bebas terhadapnya yang dimiliki semua orang tanpa adanya mekanisme kontrol, sehingga jelas dari maraknya penggunaan I-Doser ini, menimbulkan ketidaksukaan dalam diri masyarakat terhadap aplikasi ini. Disisi lainnya juga, jika terus-menurus dibiarkan maka akan menimbulkan kerugian bagi masyarakat luas selayaknyanya kerugian yang ditimbulkan oleh narkotika konvesional pada umumnya seperti timbulnya kerugian baik materiil maupun immateriil yang nominalnya sangatlah besar jika diakumulasikan dan jatuhnya korban tentu tidak dapat dihindarkan lagi, dimana korban yang berjatuhan akan semakin banyak dari waktu ke waktu, jika terus dibiarkan tanpa adanya penanganan atau kebijakan nyata dalam menanggulanginya. Maka jelas akan lebih menguntungkan dari segi pembiayaan untuk mencegah kerugian tersebut daripada menanggulangi dan kemudian memperbaiki kerusakan yang telah ditimbulkannya.

Pada akhirnya, yang terpenting dari semua pertimbangan untuk mengkriminalisasi aplikasi I-Doser adalah semua dampak negatif yang diciptakan oleh sebuah software pada perangkat elektronik tersebut, yang merasuk kedalam semua elemen masyarakat untuk kemudian menciptakan sebuah kerusakan baik itu kerusakan moral, mental bahkan kerusakan yang menimbulkan ketidakseimbangan finansial yang berujung pada proses menghalangi pewujudan tujuan nasional dalam tatanan berbangsa dan bernegara yakni menciptakan masyarakat yang adil, makmur dan sejahtera.

Indonesia telah memiliki dan menentukan tujuan bernegaranya sebagaimana dituangkan dalam Pembukaan Undang-Undang Dasar Negara Republik Indonesia 1945 dimana dinyatakan tujuannya agar masyarakat Indonesia jauh lebih cerdas, lebih makmur dan sejahtera dari sisi perekonomiannya, dapat hidup aman dan tentram serta mendapatkan 
perlakuan yang adil, yang kesemuanya itu berujung pada sebuah kebahagiaan. Oleh karenanya, perlu untuk memikirkan bagaimana menciptakan masyarakat sesuai dengan apa yang dicitakan oleh negara, jauh sebelum munculnya berbagai persoalan sosialekonomi-politik dan revolusi teknologi.

Politik hukum jelas memainkan peranannya dalam kondisi ini. Sunaryati Hartono mengatakan, ${ }^{35}$ hukum sebagai alat, sehingga secara praktis politik hukum juga merupakan alat atau sarana dan langkah yang dapat digunakan oleh pemerintah untuk menciptakan sistem hukum nasional guna mencapai cita-cita bangsa dan tujuan negara.

Penulis kemudian mempunyai pandangan mengenai pengaturan hukum di masa yang akan datang terkait narkotika pada umumnya dan narkotika digital pada khususnya bahwasannya perlu adanya pembaharuan hukum pidana melalui sebuah kebijakan reformulasi aturan hukum dengan jalur mengkriminalisasi aplikasi I-Doser sebagai narkotika digital. Reformulasi tersebut dalam pandangan penulis dititikberatkan pada Pasal 1 ayat (1) Undang-undang Nomor 35 Tahun 2009 tentang Narkotika dimana melalui pembaharuan hukum pidana, maka reformulasinya dilakukan melalui penambahan satu ayat baru dalam pasal ini untuk kemudian memperkuat pengertian dari narkotika sebagaimana yang telah diatur tersebut, dimana dalam pemikiran penulis jika dirumuskan berbunyi "Termasuk juga

35 C.F.G. Sunaryati Hartono, Politik Hukum Menuju Satu Sistem Hukum Nasional, (Bandung: Alumni, 1991), hlm. 1. pengertian narkotika yakni segala sesuatu baik berupa peralatan baik itu perangkat keras maupun perangkat lunak atau produk hasil pengembangan teknologi atau bahan-bahan baik itu terdiri dari suatu zat atau senyawa baru maupun merupakan turunan atau pengembangan dari zat yang termasuk dalam golongan-golongan narkotika yang memiliki efek sebagaimana dijelaskan dalam pasal 1 ayat (1) dan/atau ditujukan untuk memperkenalkan narkotika pada tubuh manusia."

Reformulasi aturan hukum juga dapat menyasar pada beberapa unsur-unsur yang memiliki kaitan dengan aplikasi I-Doser yang kemudian dapat dikriminalisasi. Bertitiktolak dari I-Doser sebagai objek utamanya, maka terdapat beberapa unsur terkait dalam pandangan penulis yakni antara lain adalah unsur menciptakan, memperjualbelikan, menyebarluaskan, menggunakan dengan tujuan untuk diri sendiri atau orang lain dan menghasut orang lain untuk menggunakannya.

Teknologi terus berkembang dan terbaharukan, ilmu pengetahuan semakin maju, kehidupan masyarakat semakin dinamis dan kompleks sehingga perlu sebuah langkah kedepan yang lebih maju, progresif dan visioner dalam pembangunan hukum melalui pengaturan perundang-undangan hukum di Indonesia sehingga nilai-nilai yang terkandung dalam pembukaan UndangUndang Dasar Negara Republik Indonesia serta yang terjawantahkan dalam Pancasila, dapat terwujud dan terlaksana dengan baik. 


\section{Simpulan}

Berdasarkan pembahasan yang telah dikemukakan, maka dapat ditarik kesimpulan sebagai berikut:

1. Mencermati konsep dari narkotika itu sendiri, pada dasarnya ditekankan pada efek samping yang ditimbulkan dari penyalahgunaannya. Berangkat dari konsep dasar tersebut maka dalam pandangan penulis, I-Doser dapat dikategorisasikan sebagai narkotika baru. Hal ini dengan argumentasi bahwasanya I-Doser memang bukanlah obat atau zat tapi efek yang ditimbulkannya hampir sama dengan penggunaan narkotika konvensional.

2. Implikasi yuridis dari kekosongan aturan mengenai pengaturan tentang I-Doser dalam perspektif kepastian hukum adalah aplikasi I-Doser terus merajalela dan semakin menancapkan hegemoninya untuk merusak generasi bangsa kedepannya tanpa bisa diberikan sebuah langkah hukum yang kongkrit guna mengatasi kerusakan yang ditimbulkan pada masa ini dan masa yang akan datang serta guna memberi jawaban atas keresahan yang dialami masyarakat selama ini. Cepat atau lambat, invasi teknologi akan memberikan warna baru dan dampak yang besar dalam berbagai aspek kehidupan pada umumnya dan narkotika pada khususnya.

3. Kebijakan reformulasi aturan hukum terhadap aplikasi I-Doser sebagai narkotika digital dalam ius constituendum di indonesia yakni melalui pembaharuan hukum pidana. Reformulasi dilakukan melalui sebuah kebijakan reformulasi hukum dengan jalur mengkriminalisasi aplikasi I-Doser sebagai narkotika digital. Kriminalisasi ini kemudian mengarah pada perubahan isi dari undang-undang narkotika itu sendiri, dimana kedepannya undang-undang narkotika tidak hanya mengatur narkotika konvensional tetapi juga mengatur narkotika digital didalamnya.

\section{DAFTAR PUSTAKA}

\section{Buku}

Abadinsky, Howard. Drug Use and Abuse, $A$ Comprehensive Introduction. $8^{\text {th }}$ Edition. United States of America: Wadsworth Cengage Learning, 2014. Arief, Barda Nawawi. Bunga Rampai $\begin{array}{llr}\text { Kebijakan } & \text { Hukum } & \text { Pidana, } \\ \text { Perkembangan } & \text { Penyusunan } & \text { KUHP }\end{array}$
Baru. Edisi Kedua. Jakarta: Kencana Prenamedia Group, 2014.

C.F.G., Sunaryati Hartono. Politik Hukum Menuju Satu Sistem Hukum Nasional. Bandung: Alumni, 1991.

James D. Lane dan Stefan J. Kasian dkk. Binaural Auditory Beats Affect Vigilance: Performance and Mood. 
Virginia: The Center for the Study of Complementary and Alternative Therapies, 1997.

Friedman, Lawrence. American Law. London:

W.W. Norton \& Company, 1984.

Palguna, I Dewa Gede. Pengaduan Konstitusional (Constitutional Complaint), Upaya Hukum Terhadap Pelanggaran Hak-Hak Konstitusional Warga Negara. Jakarta: Sinar Grafika, 2013.

Tongat. Dasar-Dasar Hukum Pidana Indonesia Dalam Perspektif Pembaharuan. Malang: UMM Press, 2008.

Tumpa, Harifin A. Komentar dan Pembahasan UU No. 35 Tahun 2009 tentang Narkotika. Jakarta: Sinar Grafika, 2013.

\section{Jurnal}

Le Scouarnec RP dkk. "Use of binaural beat tapes for treatment of anxiety: a pilot study of tape preference and outcomes". AlternTher Health Med Vol. 7, No. 1, (January 2001). 58. http://crawl.prod.proquest. com.s3.amazonaws.com/fpcache/ eecd31634767586ab344700c70e533b. pdf. Diakses 14 Desember 2015.

Huang, Tina L. "A Comprehensive Review Of The Psychological Effects Of Brainwave Entrainment". Alternative Therapies, Vol. 14, No. 5, (Sep/Oct 2008): 38. https://www.transparentcorp. com/downloads/Huang-Psychologic alEffectsBrainwaveEntrainment.pdf. Diakses 14 Desember 2015.

\section{Peraturan Perundang-undangan}

Undang-Undang Dasar Republik Indonesia 1945.

Undang-undang Nomor 35 Tahun 2009 tentang Narkotika.

\section{Naskah Internet}

Asosiasi Parapsikoterapi Indonesia. “Terapi Binaural Beats". http://www. binauralbeats.co.id/. Diakses 31 Oktober 2015.

Ghani, Ikin A. "Pengertian Narkotika Menurut Ahli”. http://documents.tips/. Diakses 22 April 2016.

Ikatan Cendekiawan Muslim Se-Indonesia. "BNN Masih Dalami Perihal I-Doser". http://www.icmi.or.id/. Diakses 28 Oktober 2015.

Jose, Advent. "Pengguna Smartphone di Indonesia Capai 55 Juta”. http://techno. okezone.com/read/2015. Diakses 1 April 2016.

Jurnal Riau. "BNN Tak Bisa Larang Netizen Unduh I-Doser". http://www.jurnalriau. com/read. Diakses 10 November 2015.

Kementerian Komunikasi dan Informatika. "Indonesia Raksasa Teknologi Digital Asia”. https://kominfo.go.id/index.php/ content/detail. Diakses 2 April 2016.

Meriam-Websters. "Full Definition Of Narcotic". http://www.merriamwebster.com/dictionary/narcotic. Diakses 29 Maret 2016.

Millward, Steven. "Indonesia diproyeksi lampaui 100 juta pengguna smartphone 
di 2018, keempat di dunia". https:// id.techinasia.com/jumlah-penggunasmartphone-di-indonesia-2018. Diakses 3 April 2016.

Nurjaya, I Nyoman. "Penanggulangan Kejahatan Narkotika: Eksekusi Hak
Perspektif Sosiologi Hukum”. ejournal. umm.ac.id. Diakses 22 April 2016. Primadhyta, Safyra. "Kominfo Blokir Sementara Situs Narkoba Digital I-Doser”. http://www.cnnindonesia. com/teknologi/. Diakses 10 Agustus 2016. 